\title{
Sit Sınırlarının Koruma Bağlamında Değerlendirilmesi: Niğde Kalesi ve Eskisaray Mahallesi Kentsel Sit Alanı
}

\author{
Emel EFE YAVAȘCAN ${ }^{*} 1$, Zehra GEDİZ URAK ${ }^{2}$ (I) \\ ${ }^{1}$ Niğde Ömer Halisdemir Üniversitesi, Mimarlık Fakültesi, Mimarlık Bölümü, 51000, Niğde, Türkiye \\ ${ }^{2}$ Çankaya Üniversitesi, Mimarlık Fakültesi, İç Mimarlık Bölümü, 06800, Ankara, Türkiye
}

(Alınış / Received: 07.12.2020, Kabul / Accepted: 27.05.2021, Online Yayınlanma / Published Online: 15.08.2021)

Anahtar Kelimeler Niğde, Kentsel sit, Tarihi çevre koruma, Alan yönetimi
Özet: Tarihi, Neolitik ve Kalkolitik çağlara kadar uzanan Niğde İli, geçmiş dönemlerde Kapadokya içerisinde önemli bir konuma sahip olmuş, korunması gerekli tarihi çevreler barındırmaktadır. Niğde İli kent merkezinde bir adet kentsel sit alanı bulunmaktadır. 17.09.1993 tarih ve 1535 karar numarası ile tescillenen, kentin tarihi çekirdeğini oluşturan çalışma alanı Kale, Alaeddin ve Eskisaray Mahallelerini kapsayan sit sınırı ve çevresidir. $\mathrm{Bu}$ çalışmanın amacı sit alanı sınırlarının korunmuşluk durumunun araştırılmasıdır. Çalışma alanında yapılan alan analizleri sonucu önerilen sit sınırının dışında kalan tarihi dokunun ne yazık ki sit alanı ile bir bütün olarak korunamadığı ortaya çıkmıştır. Sit sınırı biter bitmez inşa edilen yüksek katlı yapılar sit sınırı ile sınırın dışında kalan tarihi doku arasında bir duvar oluşturmuştur. Sit alanı içinde ise problemler bulunduğu ve tescilli ve tescilsiz geleneksel pek çok konutun yerinde olmadı̆̆ı tespit edilmiştir. Ayrıca, önerilen sit sınırının, Alaeddin Tepesi ve kısmi çevresini içermesi, devam eden tarihi dokuyu içine almamasının da telafisi olmayan zararların meydana gelmesine neden olduğu belirlenmiştir. $\mathrm{Bu}$ araștırmalar neticesinde, alandaki tarihi değerlerin bir bütün olarak korunması için çağdaş korumanın yönetsel boyutu olan alan yönetimine Niğde Tarihi Kent Merkezi'nin ihtiyacı olduğu anlaşılmıştır. Yönetim alanı ve etkileşim alanı sınırlarının doğru belirlenmesi ise alanın bütünleşik korunması için şarttır. Bu bağlamda, Niğde Tarihi Kent Merkezi'nde yapılan alan analizlerinden elde edilen verilerin değerlendirilmesi neticesinde yönetim ve etkileşim alanı sınırları önerilmiştir.

\section{Evaluation of Site Boundaries in The Context of Conservation: Example of Niğde Castle and Eskisaray District Urban Conservation Site}

Keywords

Niğde,

Urban site,

Historic environmental conservation,

Site management

\begin{abstract}
Niğde Province, whose history goes back to the Neolithic and Chalcolithic ages, has had an important position in Cappadocia in the past and contains historical environments that should be preserved. There is one urban site in the city center of Niğde Province. The working area, which was registered with the date of 17.09 .1993 and with the decision number 1535 and constitutes the historical core of the city, is the site boundary and its surroundings covering the Kale, Alaeddin and Eskisaray Neighborhoods. The aim of this study is to investigate the conservation status of the site boundaries. As a result of the field analysis carried out in the study area, it has been revealed that the historical texture outside the proposed site boundary cannot be preserved as a whole with the site area. High-rise buildings built as soon as the site boundary ends, formed a wall between the site boundary and the historical texture outside the boundary. It has been determined that registered and unregistered traditional dwellings have not survived to the present day. As a result of the analysis, it is seen that the proposed site boundary includes Alaeddin Hill and its partial environment, and since it does not include the ongoing historical texture, unrecoverable results have emerged. In order to preserve the historical values in the area as a whole, Niğde Historical City Center needs area management, which is the administrative dimension of contemporary preservation. The perfect decision of the boundaries of the management area and the buffer zone is essential for the preservation of the area as a whole. In this context, management area and buffer zone boundaries have been proposed as a result of the evaluation of the data obtained from the field analyses made in Niğde Historical City Center.
\end{abstract}




\section{Giriş}

Eski eserlerin onarımı ve olduğu gibi saklanması anlayışı günümüzde bir bölgenin, parçaları da dâhil olmak üzere, geçmişi ve devamlılı̆̆ını sağlayan bir bütün olarak değerlendirilmesi anlayıșına kavuşmuştur. Kentsel korumanın bütünleşik yani bütünü korumaya yönelik olması gerektiği, “Toplumun geçmişteki sosyal, ekonomik koşullarını, kültürel değerlerini yansıtan fiziksel yapısının günümüzün değişen sosyal ve ekonomik koşulları altında yok olmasına engel olmak ve çağdaş toplumla, çağdaş gelişmelerle bütünleşerek yaşamasını sağlamak" [1] şeklindeki kentsel koruma tanımlamasından da anlaşılmaktadır.

Bir alanın sit alanı ilan edilmesi kararı taşınmaz kültür ve tabiat varlıklarının korunmasında önemli bir yere sahiptir. Bir arada bulunan kültür ve tabiat varlığı taşınmazların, birlikte ve bütünlük içerisinde korunması ancak sit alanı ilanı kararıyla mümkün olabilmektedir. Bu karar ile çevre ölçeğinde koruma sağlanacaktır. Tarihi çevre korumanın amacl, tarihi yerleşmeleri yok olmaktan kurtararak, kültür mirasını günümüz yaşamıyla bütünleştirmektir [1]. Kültür ve Tabiat Varlıklarını Koruma Yüksek Kurulunun 681 numaralı ilke kararında, kentsel sit alanı; "Kentsel sitler; mimari, mahalli, tarihsel, estetik ve sanat özelliği bulunan ve bir arada bulunmaları ve bir bütün olarak o yerleşmenin ait oldukları dönemin yaşam biçimini gelecek nesillere aktarmaları sebebiyle teker teker taşıdıkları kıymetten daha fazla kıymeti olan kültürel ve tabii çevre elemanlarının (yapılar, bahçeler, bitki örtüleri, yerleşim dokuları, duvarlar, sokak ve meydanlar, v.b.) birlikte bulundukları alanlardır." şeklinde tanımlanmıştır. Kentsel sit alanın bulunduğu çevre içinde korunmasında, geliştirilmesinde etkinlik taşıyan ve kentle bütünleşmesine olanak sağlayacak kararlara konu alanlar ise etkileşim geçişsahası olarak tanımlanır [2].

Kentsel sitlerin gelecek nesillere ulaşabilmesi ve varlığını devam ettirebilmesi, güncel yaşamın gerekleri ile kaynaştırılmalarına bağlıdır [3]. Günümüzde sit sınırları içinde yer alan tarihi kent merkezleri canlılığını kaybetmiş, eskimiş, terk edilme ve yok olma sürecine girerek sahipsiz tarihi kent dokularına dönüşmüştür. Bu bağlamda Niğde kent merkezinde yer alan, kentin çekirdeğini oluşturan kentsel sit alanı da aynı özellikleri taşımaktadır. 1994 ve 2000 yıllarında yapılan koruma amaçlı projeler kâğıt üzerinde kalmıș, kentsel sitin gelişimini ve varlığını devam ettirilmesi adına gerekli uygulamalar ne yazık ki başlatılamamıştır. Sit içerisinde uzun yıllar anıtsal yapılar işlevsiz ve bakımsız halde kaderine terk edilmiştir. Sit sınırında yapılan koruma amaçlı projelerin hayata geçirilememesi tarihi kent merkezini bakımsızlığa itmiş olsa da yapıların özgün kalmasında da olumlu olmuştur. Zira koruma uygulamaları genellikle yapıların özgünlüğüne zarar verebilmekte, başarılı olamamaktadır [4]. Korumada
Niğde Kalesi ve Eskisaray Mahallesi Kentsel Sit Alanı için koruma adına uygulamaların yapılmamış olmasından daha mühim konu ise sit sınırının tarihi dokunun tamamını kapsamaması, değerli tarihi dokunun parçalara ayrılmasıdır. Yapılan analiz sonuçlarında sit sınırı kararının kentin tarihi dokusunun analizlerinin kısmi olarak dikkate alınarak verildiği anlaşılmaktadır. Öyle ki, sit alanının bitiminde yer alan Cullaz Sokak ve çevresi, Akmedrese, Sır Ali Mahallesi tarihi dokuları ne yazık ki sit alanı dışında bırakılmıştır.

Çalışmada; Niğde Tarihi Kent Merkezi'nde bulunan Niğde Kalesi ve Eskisaray Mahallesi Kentsel Sit Alanı Sınırlarının belirlenmiş olmasına rağmen, sınır içerisinde ve dışarısında koruma sorunlarının varlığı çözülmesi gereken bir problem olarak belirlenmiş ve sit sınırına dahil edilen ve edilmeyen alanların koruma bağlamında analizi ve değerlendirilmesi neticesinde Niğde Tarihi Kent Merkezi'nin koruma sorunlarının bütünleşik ve sürdürülebilir çözülebilmesini sağlayacak sit sınırı ve etkileşim bölgesi sınırları önerilmiştir. $\mathrm{Bu}$ önerileri gerçekleștirebilmek için; görsel belgeleme yöntemi ile arazide yapılan tespitler, yapı envanterleri olarak Niğde Belediyesi İmar Müdürlügü'nden temin edilen 1/1000 ölçekli hâlihazır harita üzerine işlenerek güncel bir altlık hazırlanmıştır. Analiz çalıșmaları, yapısal ölçekte; konum düzenleri, mimari değerler, özgünlük, yapısal durum, kat adetleri, çevresel ölçekte ise; çalışma alanındaki sit alanları ve kültür varlıkları, yapıların arazi ve yapı kullanımı, ulaşım ve parselasyon durumu, yapı dönemleri, topografik durumu analiz edilmiş ve Autocad programında bilgisayar ortamında paftalara aktarılmıștır. Nevşehir Kültür Varlıklarını Koruma Bölge Kurulu, Niğde Müzesi, Niğde Belediyesi vb. kurumlarda arşiv çalışmaları yapılmıştır. Sürdürülebilir kentsel koruma üzerine literatür taraması yapılarak çalışma alanı ile ilgili verilere ulaşılmıştır. Toplanan tüm bilgiler bilgisayar ortamında çakıştırılmış, kent merkezindeki alanların sahip olduğu değerler ve barındırdıkları sorunlar benzerliklerine göre gruplandırılarak farklı değer ve sorunları barındıran bölgeleme çalışması yapılmış [5] ve sonuç olarak tüm bölgeleri kapsayan sit sınırları belirlenmiştir.

\section{Niğde Kalesi ve Eskisaray Mahallesi Kentsel Sit Alanı'nın Tanımı}

Niğde Kent merkezindeki sit sınırlarının tanımına bakıldığında tarihi kent merkezinin kuzeybatısında Kayaardı Bölgesi 3.Derece Doğal Sit Alanı, batısında Tepebağları Bölgesi 3. Derece Doğal Sit Alanı ve Tepebağları 1.Derece Arkeolojik Sit Alanı yer almaktadır (Şekil 1). Niğde Tarihi Kent merkezinde ise;

1.Derece Arkeolojik Sit Alanı: Kentin tarihsel çekirdeğinde, kuzeyde; iç kale ve bazı kapı ve burçlarıyla ayakta olan orta kale ve surları, güneyinde; Alaeddin Camii ve Hatıroğlu Çeşmesi, 
bunların arasında kalan 1747 tarihli Rahmaniye Camii ve sivil mimarlık örneklerinin belirlediği bölge olup 'I. Derece arkeolojik sit sınırı ilan edilmiștir (15.07.1978/A-1207 tarih ve no ile ilan edilen arkeolojik sit sınırı Alaeddin Tepesi diye bilinen höyüğ̈̈ kapsamaktadır) [6].

III. Derece Arkeolojik Sit Alanı (Kentsel Arkeolojik Sit Sınırı): Alaeddin tepesi üzerinde, I. Derece arkeolojik sit sınırını içine alan, sur içi Kale ve Alaeddin Mahallelerini tamamen kapsayan sinırdır.

Niğde Kalesi ve Eski Saray Mahallesi kentsel sit alanı: I. ve III. Derece Arkeolojik sit alanları, Alaeddin ve Kale Mahallelerini ve sur dişında kalan Eskisaray Mahallesi'nin bir bölümünü kapsamaktadır. 13.07.2000/1305 tarih ve numara ile koruma altına alınan sit alanında; Niğde Kalesi, Kığılı Cami, Çarşı Hamamı, Rahmaniye Cami, Alaeddin Cami, Hatıroğlu Çeşmesi, Sokullu Mehmet Paşa Bedesteni, Sungurbey Cami, Rum ve Ermeni Kiliseleri, Nalbantlar Çeşmesi, Dumlupınar İlköğretim Okulu, Eskiciler ve Kıble Mescidi ve 18.-19. Yüzylllara ait geleneksel Niğde Evlerinin önemli örnekleri yer almaktadır.

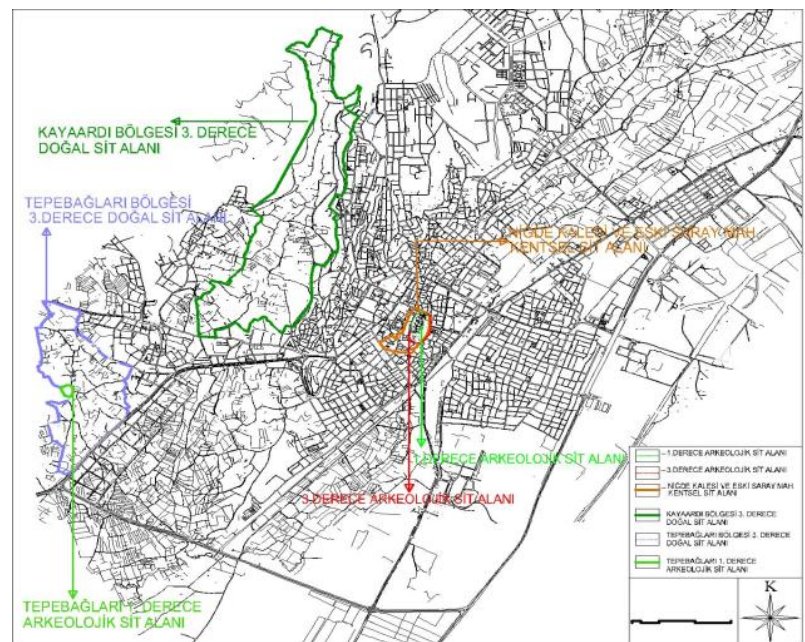

Şekil 1. Niğde Eskisaray ve Kale Mahallesi Kentsel Sit Alanının kent merkezindeki konumu ve diğer sit alanları ile ilişkisi

Kentte günümüze kadar koruma bağlamında yapılan çalışmalar sınırlıdır. Bu çalışmalar da kenti sadece fiziksel olarak ele alan yer altında ve üstündeki tüm değerleri kapsamayan çalışmalardır. Kentin bütüncül koruma yaklaşımlarından uzak olduğu görülmektedir. Bunlar; Koruma Amaçlı Niğde Kalesi Çevresi Düzenleme Projesi (1994) ve Niğde Eskisaray ve Kale Mahalleleri Koruma Planı Revizyonu (2000) çalışmalarıdır

1994 yılında Koruma Amaçlı Niğde Kalesi Çevre Düzenleme Projesi hazırlanmıştır. Projelendirme alanı kentin tarihsel çekirdeğinde, iç kale ve bazı kapı ve burçlarıyla ayakta olan orta kale ve surlarının belirlediği 'Arkeolojik Sit Alanı' ve bunu içeren tarihsel kent dokusu 'Kentsel Sit Alanı' bütününü kapsayan 13.11 ha ölçüsündedir. Niğde İli'nin 1981 tarihli imar planı uzun yıllar yürürlükte kalmıştır.
Uygulamaya başlanan bu plan ile tarihi dokuda olumsuz kararlar uygulanmıştır. Planın ilke kararları tarihsel kent dokusuna duyarlılıkla yaklaşamamıştır. Arkeolojik ve kentsel sit alanında 5-6 katlı ruhsatl yeni yapılar inşa edilmiştir. 1994 yılında yapılan plan ile tarihi dokuda yeni kararlar alınmıştır. Uygulama koşullarının güçlügü, planın uyumsuzluğu vb. sebeplerden dolayı 2000 yılında revizyon koruma planı yaptırılmıştır (Şekil 2). Projelendirme alanı kentin tarihsel çekirdeğinde, iç kale ve bazı kapı ve burçlarıyla ayakta olan orta kale ve surlarının belirlediği 'Arkeolojik Sit Alanı' ve bunu içeren tarihsel kent dokusu 'Kentsel Sit Alanı' bütününü kapsayan 15 ha ölçüsündedir. Bu planın sınırını oluşturan 'Niğde Kalesi ve Eski Saray Mah. Koruma İmar Planı Revizyonu' adıyla, 13.07.2000/1305 tarih ve karar numarası ile kentsel sit sınırı ilan edilmiştir. Daha önceki sit sınırı, bu plan ile Eskisaray Mahallesi yönündeki sınırı genişletilmiştir [5].

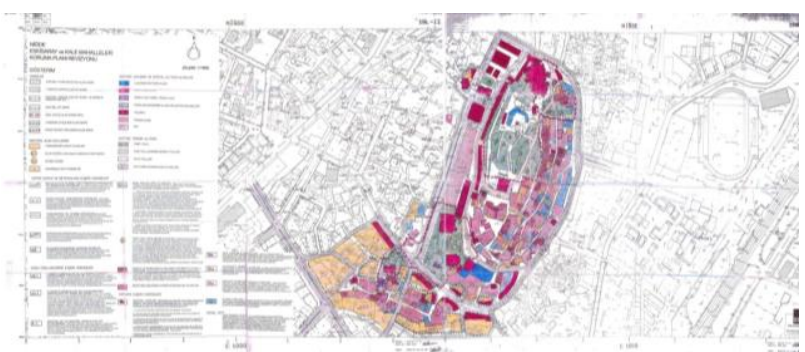

Şekil 2. Niğde Eskisaray ve Kale Mahalleleri Koruma Planı Revizyonu [7]

1994 yılında yapılan Çevre Düzenleme Projesi ile 2000 yılında yapılan Eskisaray ve Kale Mahalleleri Koruma Planı Revizyonu tarihi dokuyu önemseyen analiz, sentez ve değerlendirme çalışmalarından oluşmaktadır. Eskisaray ve Kale Mahalleleri Koruma Planı Revizyonu, Çevre Düzenleme Projesi kararlarını esas almiștır. Esas olan değișim; Eskisaray Mahallesi'nde yer alan adalar için yürürlükteki imar planı kararlarının korunmasını öneren plan kararları, 2000 yılında tarihi çevreyi önemseyen kararlar alınarak plandaki koruma sınırı bu adaları kapsayacak şekilde genişletilmiștir.

\section{Niğde Eskisaray ve Kale Mahallesi Kentsel Sit Alanının Mevcut Durumunun Fiziksel Analizi}

Çalışmada, Niğde Eskisaray ve Kale Mahallesi Kentsel Sit Alanı'nın fiziksel analizi ele alınmıștır. Analiz edilen alan, Eskisaray ve Kale Mahalleleri Koruma Planı Revizyon sınırları içerisindeki alanı kapsamaktadır. Çalışma alanında; 1. Derece Arkeolojik Sit Alanı, 3. Derece Arkeolojik Sit Alanı, Niğde Kalesi ve Eskisaray Mahallesi Kentsel Sit Alanı yer almaktadır. İlk aşamada alan için oluşturulan baz paftada çalışma alanı sınırı, sit sınırları, tescilli anıtsal ve sivil yapılar, müștemilatlar, bahçe, avlu ve yapı girişleri, kapı numaraları, harap yapılar, yerinde bulunmayan yapılar ve parsel sınırları gösterilerek çalışma alanı için güncel bir altlık elde edilmiştir. Bu paftada yerinde olmayan, günümüze ulaşmayan yapıların yoğunluğu dikkat çekicidir (Şekil 3). 


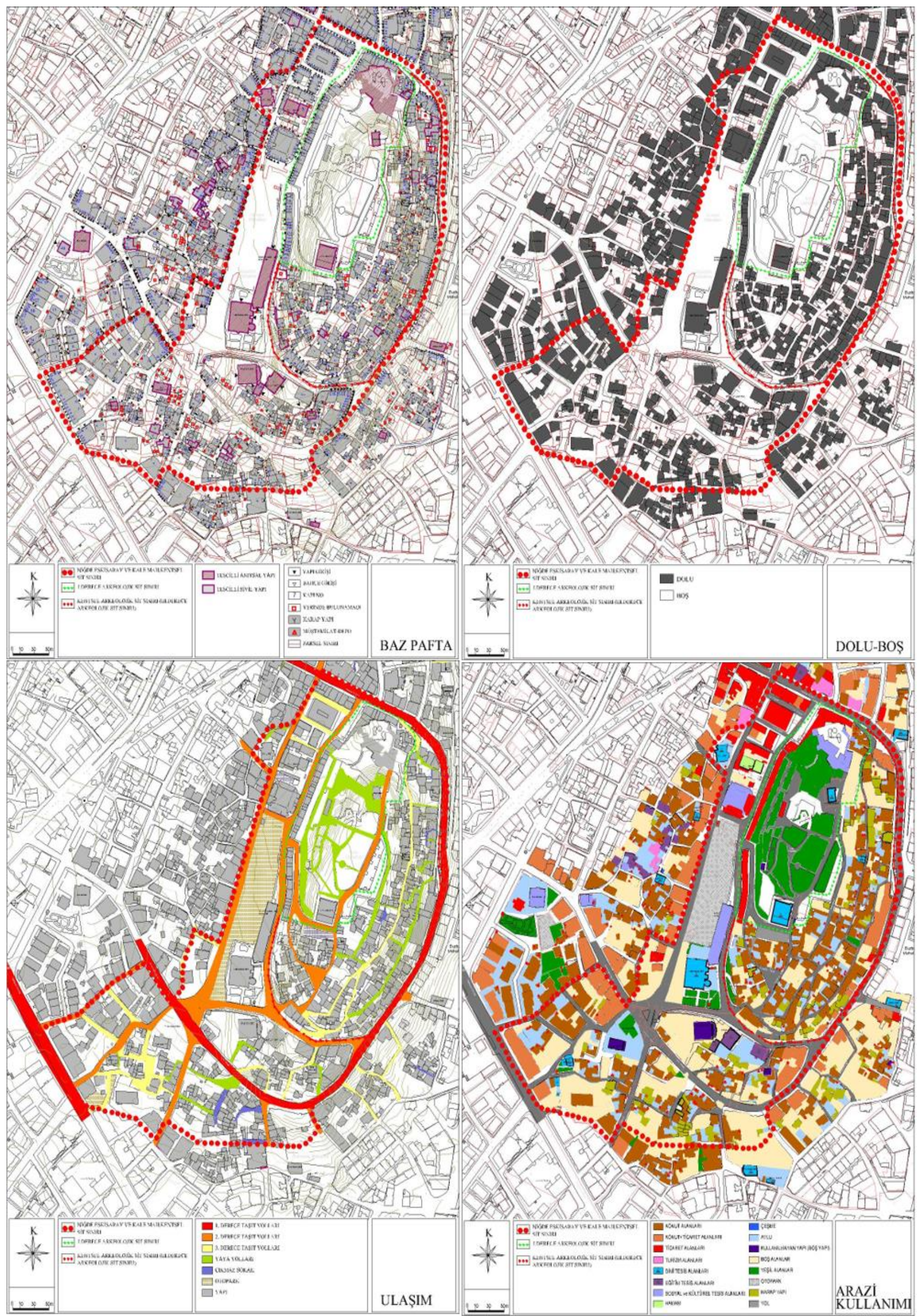

Şekil 3. Niğde Eskisaray ve Kale Mahallesi Kentsel Sit Alanı ve çevresinin fiziksel analizi 




Şekil 3 (Devamı). Niğde Eskisaray ve Kale Mahallesi Kentsel Sit Alanı ve çevresinin fiziksel analizi 
Alanda toplam 350 yapı yer almaktadır. Çalışma alanında günümüzde yerinde olmayan pek çok yapı bulunmaktadır. Hâlihazır haritada yer alan ancak günümüzde yerinde bulunmayan 40 yapı tespit edilmiştir. Bu yapılar yıkılarak yerlerine yüksek katlı yapılar yapılmıştır. Yapılan dolu-boş analiz paftasında alanın dolu ve boș ilişkisi görülmektedir (Şekil 3). Alanda boşalan parseller ve tanımsız alanlar yer almaktadır.

Kentsel sit alanında 31 adet tescilli kültürel varlık yer almaktadır (Şekil 4). Bu tescilli yapıların 16'sı anıtsal yapı niteliğindedir (Şekil 3).

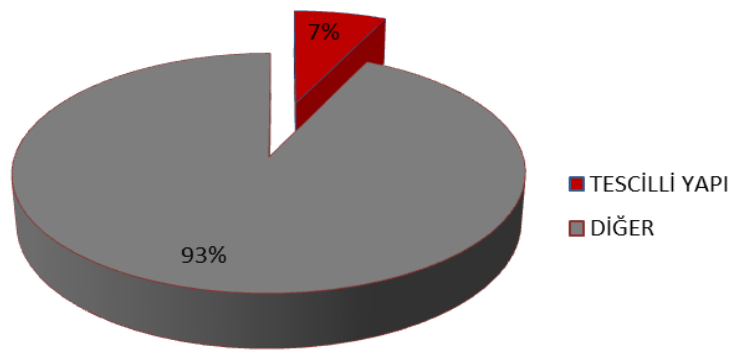

Şekil 4. Kentsel sit alanındaki tescilli yapıların dağılımı

Alan içindeki tescilli geleneksel konutlar da dâhil olmak üzere yapıların büyük kısmının yapısal durumu iyi değildir. Yapıların her geçen gün yıprandıkları, yok olma tehlikelerinin arttığı ve bir kısmının da yok olduğu tespit edilmiştir (Resim 1). Bazı yapılara yanlış müdahaleler yapılmış, özgün özellikleri değiştirilmiş, bazıları ise terk edilmiştir (Resim 2).

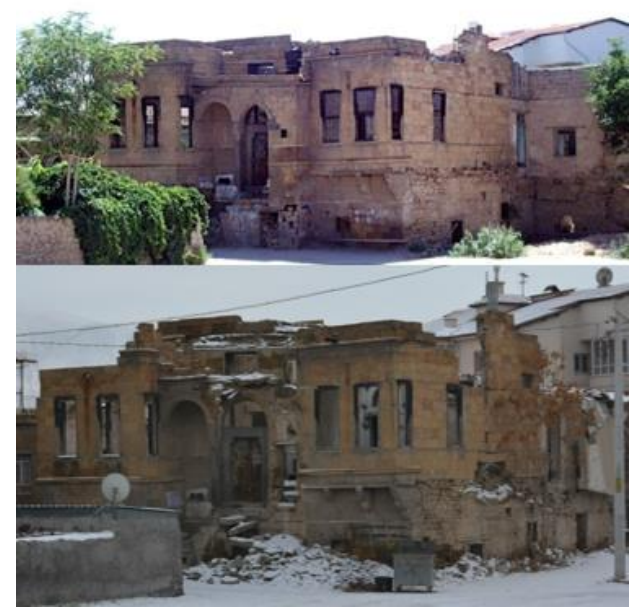

Resim 1. Eskisaray Mahallesi'ndeki tescilli geleneksel konutun 2016-2019 yılları arasındaki değişimi

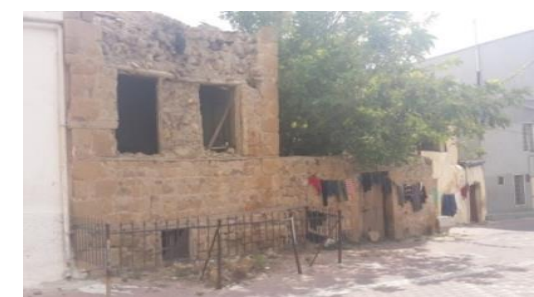

Resim 2. Kale Mahallesi'nde terkedilmiş tescilsiz geleneksel yapı, 2019
Çalışma alanı içinde taşıt yolları, yaya yolları, çıkmaz sokaklar ve otoparklar yer almaktadır (Şekil 3). Alaeddin tepesi etrafındaki taşıt yolu ringi kentin ana caddesi olan Dr. Sami Yağı Caddesine bağlanmaktadır. Alaeddin Tepesi'nde eğimli bir topografyaya oturan evler yaya yolları ile farklı kotlardan birbirlerine bağlanmaktadır. Dar sokaklarda bile araç trafiği olması problem oluşturmaktadır (Resim 3). Zamanla yok olan yapıların yerlerinin boşalmasıyla yolların ölçüleri aynı kalınlıkta devam etmemekte, yer yer genişleyen daralan taşıt yolları bulunmaktadır. Meydan niteliğindeki bu boş alanlar otopark olarak kullanılmaktadır. Boş alanların çoğu günümüzde araçların rast gele park edildiği alanlara dönüşmüştür (Resim 4). Anıtsal yapıların çevresine araçlar gelişigüzel park edebilmektedir.
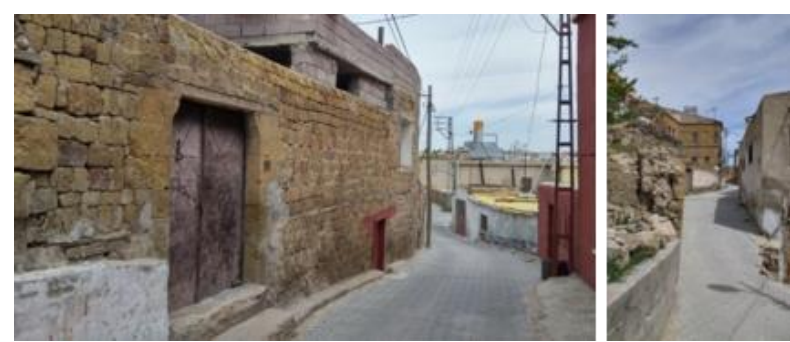

Resim 3. Kentsel sit alanında trafiğe açık olan dar sokaklar, 2016

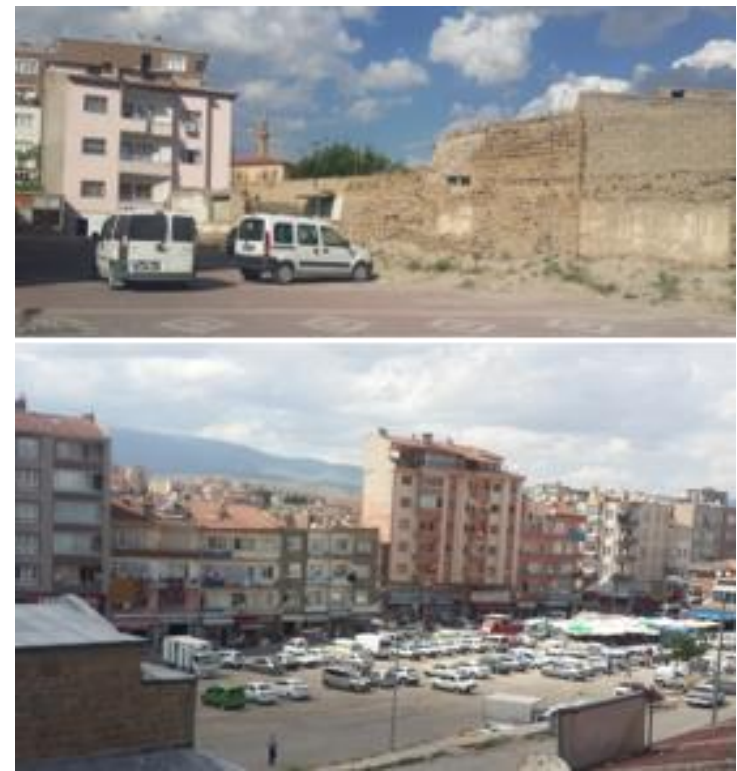

Resim 4. Kentsel sit alanındaki tanımsız alanların otopark olarak kullanılması, 2019

Çalışma alanı içindeki yapı kullanımları; konut (\%44), konut ve ticaretin bir arada olduğu yapılar (\%8), ticari yapılar (\%19), turizm yapılarl, dini tesis yapıları (\%2), eğitim yapıları, sosyal ve kültürel tesis yapıları (\%1), çeşme (\%1), hamam, kullanılmayan yapı (\%1), ve harap yapılar (\%24)dır. Yaygın kullanım konuttur (Resim 5). Açık alanlar ise yeșil alan, avlu, boș alan ve otopark olarak kullanılmaktadır (Şekil 3). Alanda turizm amaçlı kullanım yoktur 

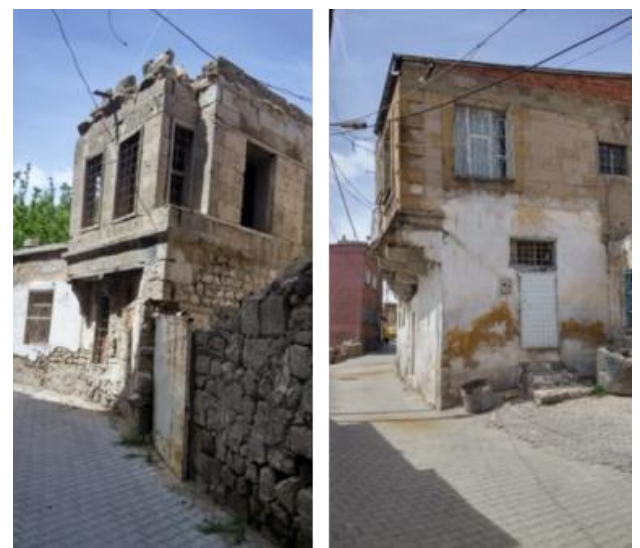

Resim 5. Alanda bulunan geleneksel konutlar, 2016

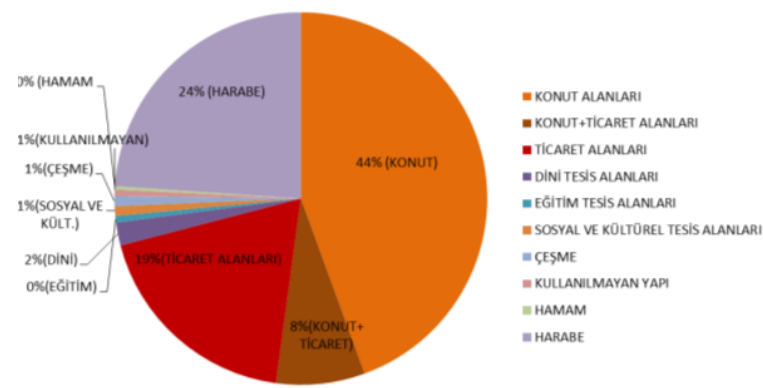

Şekil 5. Alandaki yapı kullanımı dağılımı

Çalışma alanında günümüzde belediye tarafından gönül kapısı ve kıraathane olarak Sokullu Mehmet Paşa Bedesteni kullanılmaktadır. Niğde Kalesi'ndeki mekânlar geleneksel dükkânlar ve çay evi olarak kullanılmaktadır (Resim 6). Çalışma alanındaki tarihi Çarşı Hamamı işlevini devam ettirmektedir. Alanda farklı dönemlere ait 3 adet çeşme yer almaktadır. Dini yapı olarak 2 adet mescit, 4 adet cami, 1 adet kuran kursu, 1 adet türbe yer almaktadır (Şekil 3). Alanda ticaretin yoğun olarak görüldüğü bölge, Alaeddin Tepesi'nin batı eteklerinde belediye tarafından 1980 yılında yaptırılmış tek ve iki katlı dükkânların yer aldığı bölgedir. Onarımları tamamlanan Rum ve Ermeni Kiliseleri boş durumdadır. Bunun dıșında alanda yer alan geleneksel yapıların çoğu ve Eskiciler Mescidi harap durumdadır. Sungurbey Camii'nin ise restorasyonu devam etmektedir (Șekil 5).

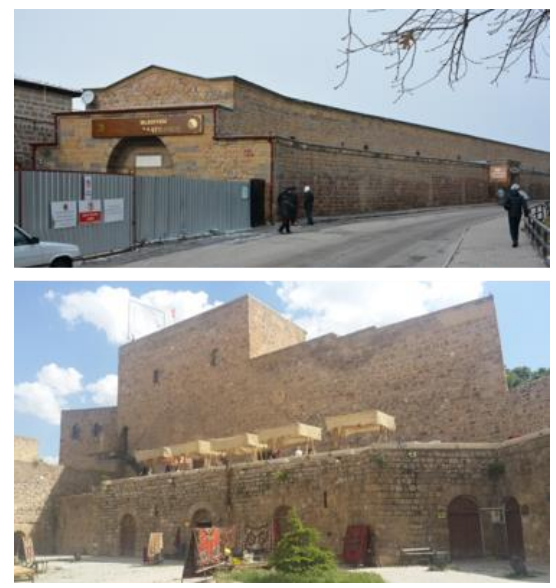

Resim 6. Çalıșma alanında sosyal ve kültürel tesis olarak kullanılan anıtsal yapılar Sokullu Mehmet Paşa Bedesteni ve Niğde Kalesi, 2019.
Çalışma alanı içinde doğu yönde yer alan Alaeddin tepesi eğimli bir topografyaya sahiptir ve tepede yer yer istinat duvarları yapılmıștır (Resim 7). Tepenin doğusunda günümüzde kuru bir yatağa dönüșen Karasu (Kızılca Deresi) yer almaktadır. Alanın diğer bölgeleri ise daha az eğimli olup daha düz arazidir. Eğim kuzey doğudan güney batı doğrultusunda olup tepenin etrafını sarmaktadır (Şekil 3).
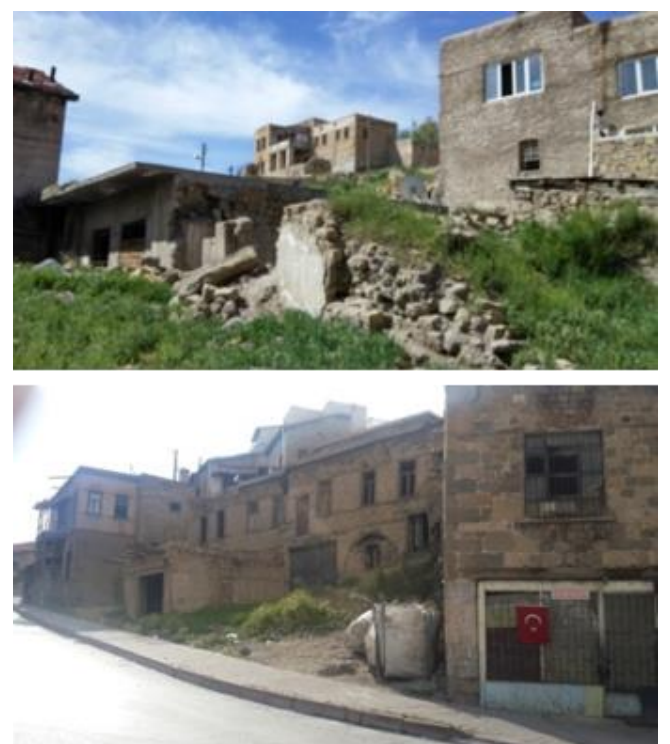

Resim 7. Kentsel sit alanında eğimli arazide bulunan konutlar, 2019

Çoğunlukla tek katlı yapıların yer aldığı çalışma alanı sınırları içerisindeki yapıların kat adetleri; tek katlı (\%51), iki katlı (\%31), üç katlı (\%9), dört katlı (\%5), beş katlı (\%2), yedi katlı (\%1) ve $8(\% 1)$ katlıdır ve alanda altı katlı yapı bulunmamaktadır. (Şekil 3, 6).

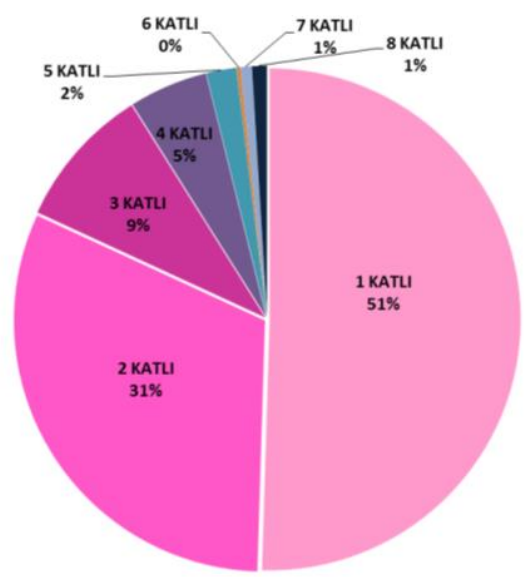

Şekil 6. Çalışma alanındaki yapıların kat adetleri durumu

Alandaki yapıların günümüzdeki durumu ile ilgili nitel gözlem ile görsel değerlendirme yapılmıștır. Bunun için eski yapılar geleneksel özellik taşıyan, taşımayan olarak ayrılmış, yakın dönemde inşa edilen yapılar ise yeni yapı olarak nitelendirilmiştir. $\mathrm{Bu}$ yapılardan harap durumda olanlar da belirlenmiștir. (Şekil 3). Alandaki yapıların \%40'ı geleneksel özellik gösteren, \%49'u geleneksel özellik göstermeyen, $\% 11$ 'i ise yeni yapıdır (Şekil 7). 


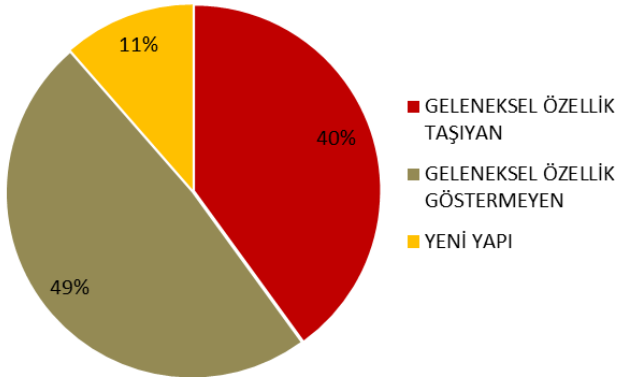

Şekil 7. Çalışma alanındaki yapıların dönemsel analizi

\section{Eskisaray ve Kale Mahallesi'ndeki Koruma Amaçlı Plan ve Uygulamaların Değerlendirilmesi}

Kentte günümüze kadar koruma bağlamında yapılan çalışmalar (Koruma Amaçlı Niğde Kalesi Çevresi Düzenleme Projesi,1994 ve Niğde Eskisaray ve Kale Mahalleleri Koruma Planı Revizyonu, 2000) analizleri ve raporları ile koruma ve geliştirmeye yönelik olumlu kararlara sahiptir. Ancak kenti sadece fiziksel nitelik kapsamında ele alan görsel olarak iyileştirmenin ötesine geçemeyen, kentin bir kısmı ele alan ve geleneksel dokunun tamamını kapsamayan planlardır. Planın diğer önemli sorunu uygulamaların finansmanına ve planın izlenmesi ve güncellenmesine yönelik öneriler getirilmemiş olmasıdır. Pek çok Koruma Amaçlı İmar Planda da görüldüğü gibi; sosyal ve ekonomik sorunların çözümüne yönelik alternatiflerin üretilmediği, tarihsel katmanların dikkate alınmadığı, sadece fiziksel mekânı düzenlemeye odaklanan planlar Niğde Kalesi ve Çevresi Koruma Amaçlı İmar Planı'nda da uygulanabilir ve sürdürülebilir olamamıştır.

Yapılan planlar sonrasında 2007 yılında Niğde Kalesi restore edilmiştir. Kale çevresinde bodur bitkilerin oluşturduğu alanlar bölgenin farklı amaçlarla kullanılmasına, güvensiz ve tehlikeli bir yer haline gelmesine neden olmuştur. Bu sebeple alanda peyzaj düzenlemeleri yapılmış, alanın bu bitkilerden temizlenerek açığa çıkartılması sağlanmıştır. Ayrıca Çevre Düzenleme Projesinde onarılarak kapalı çarşı işlevi önerilen yapı için, Koruma revizyon planında kapalı çarşı ya da sanat atölyeleri işlevi önerilmiştir. Sokullu Mehmet Paşa Bedesteni onarılarak, kapalı çarşı olarak bir dönem kullanılsa da sonrası uzun yıllar işlevsiz kalmıştır. Her iki planda da sit alanında yer alan iki kilise için çevresindeki yapılar ve açık mekânlar ile bir bütün düşünülerek onarım ve geliștirme hedeflenerek kültür ve sanat merkezleri olarak kullanılmaları önerilmiştir. Ancak bakımsız Ermeni Kilisesi ve harap durumda olan Rum Kilisesi planlar sonrasında hiçbir müdahale edilmemiş kaderlerine terk edilmiştir. Yapılan Niğde Eskisaray ve Kale Mahalleleri Koruma Planı Revizyonu'ndan yaklaşık 19 yıl sonra, Rum Kilisesi 2019 yılında onarllabilmiştir. Kiliselerin çevresindeki geleneksel yapılar ise yok edilmiştir (Resim 8). Günümüzde bu kiliseler halen işlevsizdir.

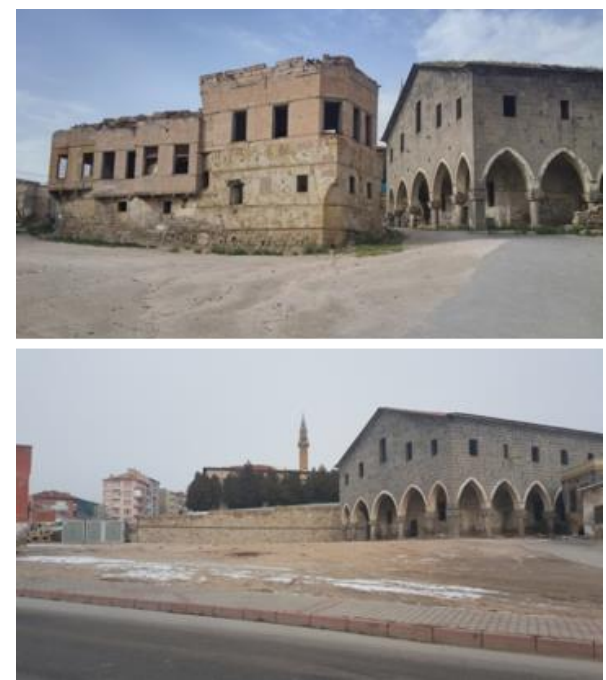

Resim 8. Üstte 2016 yllında harap Rum Kilisesi ve yakınındaki geleneksel konutlar, altta 2019 yılında onarılan Rum Kilisesi ve yok edilen geleneksel konutlar

Niğde Tarihi Kent Merkezi için yapılan alan analizleri (Şekil 3) neticesinde, kentsel sit alanı sınırının kent merkezindeki tarihi değerlerin tamamını kapsamadığı; Cullaz Sokak ve çevresi, Akmedrese ve çevresi ve Sırali Mahallesi'nin sit sınırına dâhil edilmediği belirlenmiştir. Sit sınırı dışında bırakılan bu alanların korunması için revizyon imar planları yapılmışsa da bu planlarda da telafisi olmayan kararlar alınmıştır (Şekil 8). Sit sınırı biter bitmez yüksek katlı yapılar inşa edilmiş, sit sınırının bitiminde yer alan geleneksel yapilar ve anitsal eserler göz ardı edilmiştir. Anıtsal nitelikteki değerli yapıların hemen karşısında apartmanların yükselmesine izin verilmiş, alanın dokusu ne yazık ki tahrip edilmiştir. Bu yüksek katlı yapıların inşa edilmesine izin verilmeseydi, sit sınırına dâhil edilseydi, günümüzde, bu apartman dizisinin kesintiye uğrattığı Kale Mahallesi, Cullaz Sokak bütünlüğü korunabilecek, aradaki yüksek katlı yapılar duvar gibi iki alanı birbirinden ayıramayacaktı (Şekil 3, Resim 9). Cullaz Sokak, geleneksel konutların yoğunlaştığı ve günümüze ulaştığı kentin en merkezi yerinde bulunan özgün tarihi dokunun okunabildiği kentteki ender sokaklardan birisidir [8]. Korumanın başlangıcl olarak sit sınırı içine dâhil edilmesi bu alanın günümüze çevresi ile bir bütün olarak ulaşmasını sağlayabilecek ve doğru belirlenmeyen bir sit alanı sınırının telafisi olmayan hatalı sonuçları görülmeyecekti.

Verilen plan kararları doğrultusunda uygulamalar irdelenirse; birkaç yapının onarımı, kısıtlı peyzaj düzenlemeleri dışında onarım çalışmalarının, işlevlendirme önerilerinin, meydan düzenlemelerinin, özel proje alanlarının, kentsel teknik altyapı kararlarının büyük ölçüde uygulama olanağı bulamadığı görülmektedir. Cephe, sokak ve meydanlara, doku özelliklerine ve binalara yönelik kararların çoğu uygulanmamıştır. Bazı konutlarda 


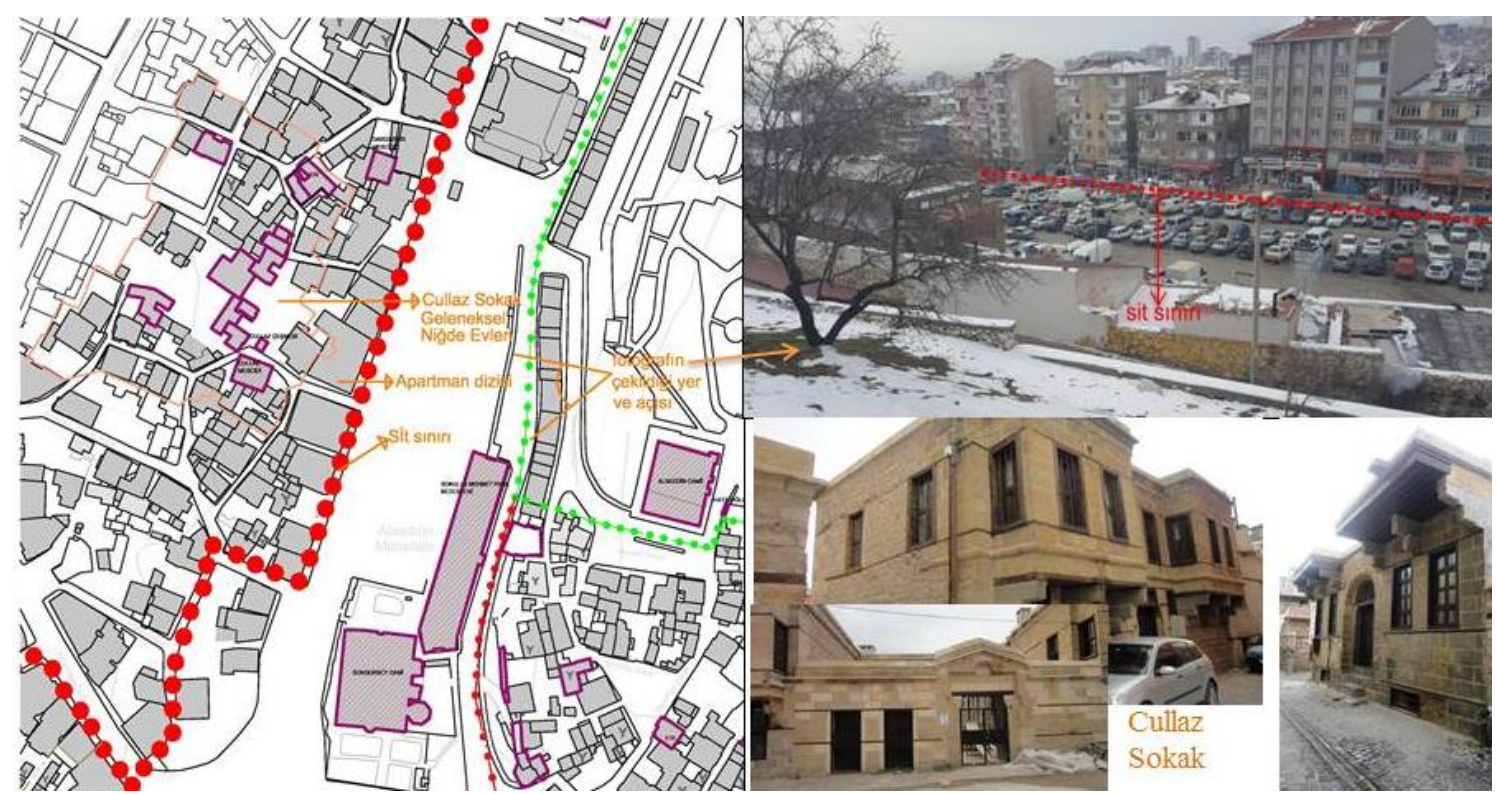

Resim 9. Üçüncü Derece Arkeolojik ve Kentsel Sit Sınırının geçtiği bölge, yüksek katlı yapılar dizisi ve sitin ardında kalan Cullaz Sokak

vatandaş tarafından basit onarımlar yapılmıştır. Alandaki Geleneksel Niğde Evlerinin hiçbirinde bu yapıları yaşatmaya yönelik restorasyon çalışması yapılmamıștır. Koruma amaçlı imar planı ile sadece sit sınırı belirlenmiș, plan uygulama şansı bulamamıș, alan kaderine terk edilmiştir.

Alan ile ilgili son gelişme ise; alanın 3 Mart 2020 tarihinde 2219 sayılı karar ile "Yenileme Alanı" ilan edilmesi ve bu kararın 4 Mart 2020 tarih ve 31058 sayılı Resmî Gazetede yayınlanarak yürürlüğe girmesidir. Yenileme alanında uygulanacak kentsel dönüşüm modelinin ise Niğde Belediyesi ile TOKİ arasında yapılacak bir protokol ile gerçekleștirilmesi planlanmaktadır.

\section{Sonuç ve Öneriler}

Alanda yapılan analizler (Bölüm 3) sonucunda;

- $\quad$ Niğde Kalesi ve Eskisaray Mahallesi Kentsel Sit Alanının da sit sınırları içinde yer alması, günümüze büyük oranda korunmuş olarak ulaşmasını sağlamıștır. Bu durum sit sınırları içine alınmanın tarihi çevre korumanın ilk ve önemli adımlarından olduğunu göstermektedir.

- Pek çok geleneksel yapı ve dokunun sınır dışında bırakıldığı belirlenmiştir (Şekil 3-Şekil 7). Bu alanlardan biri Cullaz Sokak, bir diğeri ise anıtsal bir yapı olan Akmedrese ve çevresi, günümüzde geleneksel evlerin azaldığı ve harap olduğu, içerisinde külliye ve önemli tarihi yapıların yer aldığı Sırali Mahallesidir (Şekil 8). Bu alanlar sit sınırı içine dâhil edilmiş olsa idi, yakın çevrelerindeki geleneksel doku bütünleşik korunarak günümüze ulaşmaları sağlayabilecekti.
Dokunun karma değerleriyle bir bütün olarak korunamadığı, kültürel miras yönetiminin sağlanamadığı bir bölge olan Niğde Tarihi Kent Merkezi'nin koruma sorunları bulunmaktadır. Alandaki tarihi değerlerin bir bütün olarak korunması için çağdaş korumanın yönetsel boyutu olan alan yönetimine Niğde Tarihi Kent Merkezinin ihtiyacı bulunmaktadır. 1980'ler ile çağdaş koruma anlayışının bütünleşik koruma amacı içinde alan yönetimi vurgusu ilk olarak uluslararası arenada kullanılmaya başlanmıştır. Tarihi kentsel alanların korunmasının; ancak sosyo-ekonomik gelişme her düzeydeki kent-bölge planlaması politikaları ile bir bütün oluşturduğunda etkili bir biçimde gerçekleştirilebileceği vurgulanmıştır [9]. Esas olarak UNESCO Dünya Miras Merkezi'nin, Dünya Mirası listesindeki alanlar için yönetim planı hazırlanması talebi üzerine bu alandaki çalışmalar yoğunluk kazanmıştır. Sürdürülebilir bütünleşik korumada, kaynakların etkin kullanımını sağlayan "alan yönetimi" modeli öngörülmektedir. Bu sebeple sürdürülebilir koruma, güncel bir yaklașım olan alan yönetimi yaklaşımı ile tarihi çevrelerde uygulanmalıdır. Ayrıca yerleșimlerin barındırdığı uygarlık izlerinin dâhil edildiği koruma politikalarının geliștirilmesi gerekmektedir.

Tarihi, estetik ve kültürel, ekonomik, sosyal, sembolik özellikler taşıyan, Unesco Dünya Miras Geçici Listesinde yer alan Niğde'nin tarihi anıtları Alaeddin Tepesi ve çevresinde (kentsel sit alanında) yer almaktadır (Şekil 3, Şekil 8). UNESCO'ya göre sınırlar, varlığın miras olma değerini insan elinin uzanmasının tehlikelerinden ve aday gösterilen alanın dışındaki kaynakların kullanılmasının etkilerinden korumak için istisnai evrensel değere sahip alanın hemen bitişiğindeki yeterince araziyi de kapsamalıdır. Aday gösterilen varlığın sınırları, milli parklar veya doğal 
rezervler, biyosfer rezervleri veya tarihi koruma bölgeleri gibi mevcut veya teklif edilen bir veya daha fazla koruma alanı ile çakışabilir. Koruma için belirlenen bu alanlar birkaç yönetim bölgesi ihtiva ederken, bu yönetim alanlarının yalnızca birkaçı kaydedilme için gerekli kriterleri karşılamaktadır [10]. Tampon bölge (etkileşim alanı), "Alan Yönetimi ile Anıt Eser Kurulu'nun Kuruluş ve Görevleri ile Yönetim Alanlarının Belirlenmesine İlişkin Usul ve Esaslar Hakkında Yönetmelik" de: "Sit bölgeleri ile bütünlük gösteren, yoğunluk ve yerleşme düzeninin sit bölgeleri ile uyum içinde oluşması ve gelişmesi öngörülen, sit alanını bütünleyen, etkileyen ya da ondan etkilenen ve sit alanı ile koruma amaçlı imar planına konu olmayan alanlar arasında geçiş sağlayan alanlar olarak tanımlanmaktadır" [11]. Yönetim alanı ve etkileşim alanı sınırlarına doğru karar verilmesi alanın bir bütün olarak korunması için şarttır. Bu sebeple gerekli analizlerin yapılarak sınırların alandaki değerleri kapsadığından emin olunması gerekmektedir.

Çalışma sonucunda alan analizleri dikkate alınarak etkileşim sahası önerilmiştir (Şekil 8). Niğde Belediyesi tarafından Cullaz Sokak (2011), Akmedrese ve çevresi (2010) ve Sırali Mahallesi (2011) için revizyon imar planları yaptırılmıştır. Bu çalışma kapsamında yapılan analiz ve değerlendirmeler sonucunda; etkileşim sahası sınırları oluşturulurken bu sınırlar dikkate alınmıştır. Alanın bir bütün olarak korunması ve yönetilmesi için Akmedrese ve Çevresi, Cullaz Sokak Revizyon İmar Planı Sınırları ve Sırali Mahallesi için oluşturulan revizyon imar planı sınırları etkileşim sahasına dahil edilmiștir (Şekil 8). Bu sınırlar dışında Kentsel sit alanı ile Cullaz Sokak, Akmedrese, Sirali Mahalleleri revizyon imar planları sınırları arasında kalan alanlar, Murat Paşa Külliyesi ve çevresi, Sırali Mahallesi'nin doğusunda yer alan Şahin Ali Mescidi ve Çeşmesi'nin de yer aldığı tarihi doku, kentsel sit alanının güney ve güney doğusunda yer alan pek çok harap geleneksel konutun, Hanım Camii, Burhan Mescidi, Kesikbaș Camii ve Türbesi'nin yer aldığ tahrip olmuş tarihi dokuyu içerisine alan etkileşim sahası (tampon bölge) önerilmiştir (Şekil 8). Koruma alanı ve etkileşim sahası yönetim planı sınırını oluşturmaktadır. Alanda günümüze ulaşan değerlerin acil müdahale ihtiyacında olmaları ve gelecek nesillere ulaşamama risklerinin bulunması sebepleriyle, alanın bir bütün şeklinde algllanarak korunması amaçlandığından etkilenme geçiş bölgesi önerilmiştir. Özgün dokunun gün geçtikçe bozulması, harap yapı sayısının artması bu alanın bir bütün olarak korunmasinı ve yönetilmesini gerektirmektedir. Alanın güçlü ve zayıf yönleri ile alanın sahip olduğu firsat ve tehditler belirlendikten sonra koruma politikaları ve koruma ilkeleri belirlenip bu politika ve ilkeler çerçevesinde fiziksel ve işlevsel müdahaleler yapılarak kültürel mirasın yönetimi sağlanmalıdır.

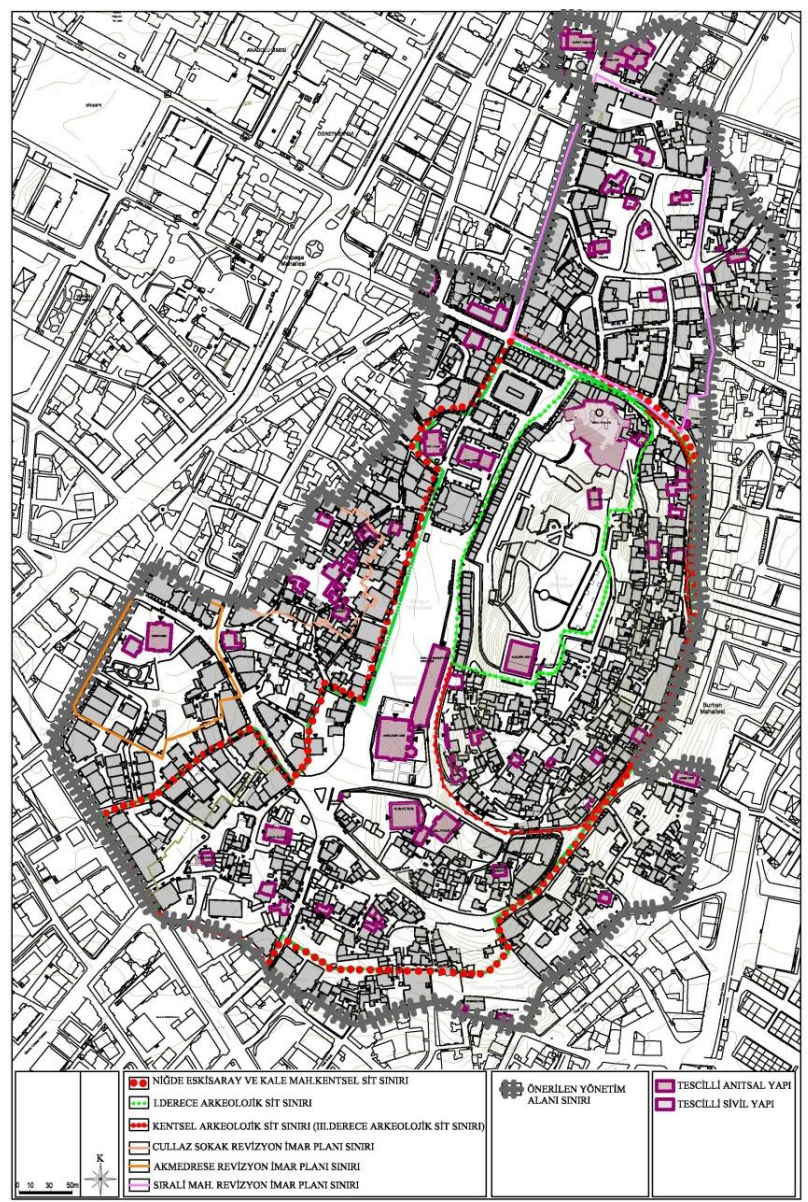

Şekil 8. Niğde Tarihi Kent Merkezindeki tüm değerleri ve sınırları kapsayan yönetim ve etkileşim alanı önerisi

\section{Teşekkür}

Bu çalışma Gazi Üniversitesi Fen Bilimleri Enstitüsü Mimarlık Ana Bilim Dalında, 2019 yılında tamamlanmış doktora tezi çalışmalarından yararlanılarak oluşturulmuştur.

\section{Etik Beyanı}

Bu çalışmada, "Yükseköğretim Kurumları Bilimsel Araștırma ve Yayın Etiği Yönergesi" kapsamında uyulması gerekli tüm kurallara uyulduğunu, bahsi geçen yönergenin "Bilimsel Araştırma ve Yayın Etiğine Aykırı Eylemler" başlığı altında belirtilen eylemlerden hiçbirinin gerçekleştirilmediğini taahhüt ederiz.

\section{Kaynakça}

[1] Ahunbay, Z. 1999. Tarihi Çevre Koruma ve Restorasyon. İkinci Baskı, Yapı Endüstri Merkezi Yayınları, Türkiye, 27s.

[2] İlke Kararları Kentsel Sitler, Koruma ve Kullanma Koşulları. https://teftis.ktb.gov.tr/TR174602/681-nolu-ilke-karari-kentsel-sitlerkoruma-ve-kullanma-.html (Erişim Tarihi: 07.12.2020).

[3] Örnek Özden, E. 2006. 'Kentsel Sit Alanı' İlanı 'Mutlak Korunuyor' Anlamina Geliyor Mu? 
https://dergipark.org.tr/tr/download/articlefile/76067 (Erișim Tarihi: 21.03.2021).

[4] Yılmaz, A. 2000. Kentsel koruma alanlarında planlama ve kentsel tasarım ilişkileri Ankara, Afyon, Konya, Avanos, Divriği Örnekleri. Gazi Üniversitesi, Fen Bilimleri Enstitüsü, Yüksek Lisans Tezi, 137s, Ankara.

[5] Efe Yavaşcan, E. 2019. Çok katmanlı tarihi kent merkezlerinin korunması için yönetim planı modeli araştırması: Niğde Tarihi Kent Merkezi Örneği. Gazi Üniversitesi, Fen Bilimleri Enstitüsü, Doktora Tezi, 196-203s, Ankara.

[6] Açıkgöz, F., Demir F., Tektaş, M., Eryaman, M. 2009. Niğde Kültür Envanteri. Niğde Valiliği İl Kültür ve Turizm Müdürlüğü Yayınevi, Ankara.

[7] Anonim, 2021. Niğde Eskisaray ve Kale Mahalleleri Koruma Planı Revizyonu. Niğde Müze Müdürlüğü Arşivi, Niğde.

[8] Urak G., Efe Yavaşcan E. 2015. Niğde Cullaz sokak koruma uygulamasının kullanımda değerlendirilmesi. 2. Ulusal Yapı Kongresi ve Sergisi Yapı Üretimi, Kullanımı ve Koruma Süreçleri, Ankara, 281-293.

[9] ICOMOS. 1987. Charter for the conservation of historic towns and Urban areas Washington Charter,

https://www.icomos.org/charters/towns_e.pdf (Erişim Tarihi: 04.10.2018).

[10] UNESCO 2013. Basic Texts 2013 EDITION of the 2005 Convention on the Protection and Promotion of the Diversity of Cultural Expressions, http://unesdoc.unesco.org/images/0022/0022 53/225383E.pdf (Erișim Tarihi:26.07.2021).

[11] T.C. Mevzuat Bilgi Sistemi. 2005. Alan Yönetimi ile Anıt Eser Kurulunun Kuruluş ve Görevleri ile Yönetim Alanlarının Belirlenmesine İlişkin Usul ve Esaslar Hakkında Yönetmelik. https://www.mevzuat.gov.tr/mevzuat?Mevzuat No=9637\&MevzuatTur=7\&MevzuatTertip $=5$ (Erişim Tarihi: 26.07.2021). 